\title{
輸血機能評価認定制度（I\&A 制度）における東海支部の現状と展望
}

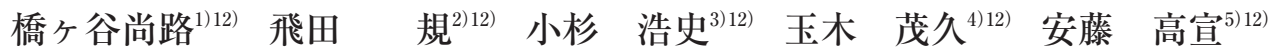 \\ 長谷川勝俊(6) 丸2) 丸美津子 ${ }^{712)}$ 森本 剛史 ${ }^{8122}$ 伊藤 裕子 ${ }^{912)}$ 井上 千好1012) \\ 進藤 仁 $^{1112)}$ 加藤 栄史 $^{512)}$ \\ キーワード：輸血機能評価認定制度 (I\&A 制度), I\& A 推進会議
}

\section{はじめに}

輸血機能評価認定制度 (I\&A 制度) (以下, I\&A)は, 日本輸血・細胞治療学会（以下，学会）にて医療施設 における輸血医療の安全管理を認証するために 2005 年より全国統一基準で認定が開始され, 2016 年にI\&A 認定基準が ver.5に変更されるとともに, 輸血機能評価 制度と和名も付されて制度が刷新された 機に I\&A 東海支部では 4 県 (愛知・岐阜・三重・静岡) の I\& A 視察員（以下, 視察員）12名からなる I\&A 東海支部推進会議（以下，本会議）を組織した。我々 は，これまでの活動を評価するとともに，I\&Aに関す るアンケートを行い，今後の認定施設拡大への課題と 視察員の拡充に向けたシミュレーションを行ったので 報告する。

\section{方 法}

\section{1. 活動評価}

I\& A 認定基準が ver.5に変更された以後の時期（以 下, ver.5)の 2016 年 1 月〜2018 年 3 月の視察回数と認 定施設数をＩ\& A 認定基準が ver.4を使用していた時 期（以下, ver.4）と比較した

\section{I \& A 認定や視察員に関するアンケート調査}

2018 年 3 月 1 日 30 日の期間で, 認定施設として東 海地区 4 県内の認定施設と I\&A 受審済みで認定待ちの 2 施設を,未受審施設として輸血管理料 I 取得施設で I\& $\mathrm{A}$ 未受審施設を，また視察員として東海地区 4 県内に 在籍する視察員を対象としてWebによる調查を行った.

認定施設に対しては(1)視察員在籍状況，(2)受審の提 案者, (3)視察準備に苦慮した点, (4)認定施設になって よかった点について，未受審施設に対しては(1)視察員 在籍状況, (2)どのようになればI\&A を受審するか, (3) 受審を阻害する要因について, 視察員に対しては(1)年 齢, (2)輸血業務改善指導の経験，(3)視察能力維持に必 要と考える 5 年間の視察経験数について質問した.

\section{3. 認定施設拡充に向けたシミュレーション}

ver.5 移行当初に I\& A 認定施設になることが期待さ れた輸血管理料 I 取得施設 認定されると仮定した場合の施設拡充と必要な視察員 確保の見通しを推測するためのシミュレーションを行っ た.

\footnotetext{
1）焼津市立総合病院中央検査科

2）磐田市立総合病院外来化学療法センター

3）大垣市民病院血液内科

4）日本赤十字社伊勢赤十字病院血液内科・輸血細胞治療部

5）愛知医科大学病院輸血部

6) 藤田医科大学施設部

7）三重大学附属病院輸血・細胞治療部

8）松波総合病院輸血部

9）大垣市民病院輸血センター

10）畿内会岡波総合病院中央検査部

11）静岡市立静岡病院看護部

12）I\&A 東海支部推進会議

〔受付日：2018 年 10 月 4 日，受理日：2019 年 3 月 22 日〕
} 
表 1 視察回数と新規認定施設数における ver. 4 期 間と ver. 5 期間の比較

\begin{tabular}{l|c|c|c|c}
\hline \multirow{2}{*}{} & \multicolumn{2}{|c|}{ 視察回数 } & \multicolumn{2}{c}{ 新規認定施設数 } \\
\cline { 2 - 5 } & 合計 & 月平均 & 合計 & 年平均 \\
\hline $\begin{array}{l}\text { ver. } 4 \\
10 \text { 年間 }\end{array}$ & 28 & 0.23 & 19 & 1.9 \\
$\begin{array}{l}\text { ver. } 5 \text { カ月 } \\
2 \text { 年 } 3 \text { カ月 }\end{array}$ & 18 & 0.67 & 10 & 4.4 \\
\hline
\end{tabular}

ver. $4: 2006$ 年 1 月 2015 年 12 月までの 120 カ月の期間 ver. $5: 2016$ 年 1 月 2018 年 3 月までの 27 カ月の期間 視察回数は, ver. 5 期間は ver. 4 期間に比べ 1 カ月あたり 約 2.9 倍増加した. 新規認定施設数は, ver. 5 期間は ver. 4 期間に比べ 1 年あたり約 2.3 倍増加した。

\section{結果}

\section{1. 活動評価}

視察は ver. 4 では 2006 年 1 月〜 2015 年 12 月までの 120 カ月で 15 施設に対して 28 回 (0.23 回/月) 実施し ていた. ver.5 では 2016 年 1 月〜 2018 年 3 月までの 27 カ月で 18 施設に 18 回 (0.67 回/月) 実施し, 1 力月あ たりの I\&A 実施頻度は約 2.9 倍増加した。

新規認定施設数は ver.4 では 19 施設 (1.9 施設/年), ver.5 では 10 施設 (4.4 施設/年) が認定され， 1 年あた り約 2.3 倍増加した（表 1$).$

\section{I \&A 認定や視察員に関するアンケート調査}

1）認定施設

対象となった 30 施設中 21 施設から回答を得て，回 収率は $70.0 \%$ であった。

21 施設のなかで視察員が在籍している施設は 17 施設 であり，在籍率は $81.0 \%$ であった（図 1 ).

受審の提案者は「輸血部門の責任者」が 9 施設で内 訳（以下括弧内）は $42.9 \%$ と最も多く，次に「その他 の輸血部門職員」が 7 施設 $(33.3 \%)$ と日常的に輸血業 務に携わる輸血部門関倸者が全体の $76.2 \%$ を占めた。 それ以外は「施設管理者」が 1 施設 (4.8\%) で， 4 施設 (19.0\%）が「施設外」の合同輸血療法委員会の医師と 学会所属の医師の勧めで受審した（図 2A）。

視察準備に苦慮した点（複数回答可）は「視察前資 料の準備」が 17 施設（81.0\%）と最も多く, 次に「受 審申請から視察までの調整」が 10 施設 (47.6\%) で, 「施設管理者や現場責任者への説明」は 8 施設 (38.1\%) であった（図 2B).

認定施設になってよかった点の有無は「ある」が 15

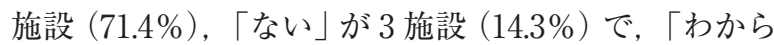
ない」が 3 施設 $(14.3 \%)$ であった.「ある」の施設で は「冷蔵庫の購入のきっかけになった」,「看護部門の 協力が得やすくなった」など輸血部門の認知度向上へ の効果を挙げていた。「ない」と「わからない」の施設 では認定期間が短く「今後の活動次第」と効果を期待 する意見があった（図 $2 \mathrm{C}$ ）。

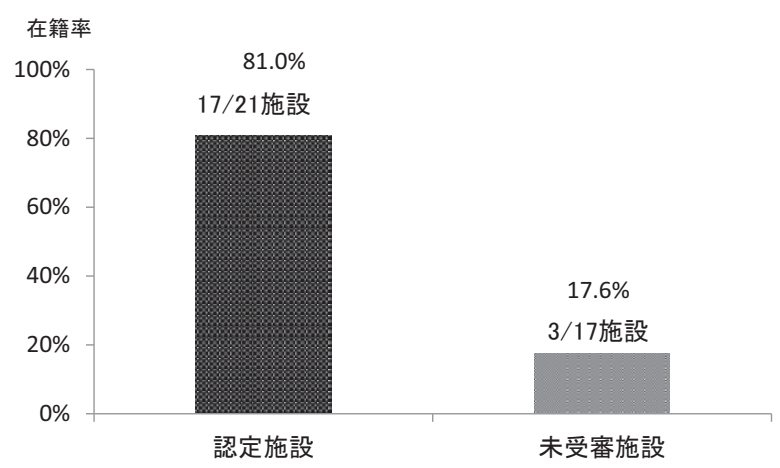

図 1 視察員の在籍状況

認定施設の視察員在籍率は $81.0 \%$ で, 輸血管理料 I 取得の I\&A 未受審施設の $17.6 \%$ に比べ， 4.6 倍である.

2) 輸血管理料 I 取得の I\& A 未受審施設

対象となった 23 施設中アンケート協力に同意を得た 17 施設から回答を得て, 回収率は $73.9 \%$ であった.

そのうち, 視察員在籍施設は 3 施設で, 在籍率は $17.6 \%$ であった（図 1).

どのようになれば I\&A を受審するか（複数回答可） については, 回答のあった 11 施設のなかで「I\&A が診 療報酬項目になる」が 9 施設 $(81.8 \%)$ で最も多く, 「自施設内での問題解決」が 6 施設 $(54.5 \%)$, 「I\&A の利点がさらに普及する」が 1 施設（9.1\%）であった (図 $3 \mathrm{~A}$ ).

受審を阻害する要因（複数回答可）については，回 答のあった 10 施設のなかで「人員不足で業務多忙」と 「経営上の利点がない」が 7 施設 (70.0\%) で最も多く, 「I\&A の理解が得られない」が 2 施設 (20.0\%), 「事務 手続き上の問題」が 1 施設（10.0\%）であった（図 3 B).

3) 視察員

対象となった 66 名中 36 名から回答を得て, 回収率 は $54.5 \%$ であった。

年齢は 50 代が 18 名（50.0\%）で最も多く，40 代が 10 名 $(27.8 \%), 60$ 代以上が 5 名 (13.9\%)，30 代が 3 名 (8.3\%) と 50 代以上が $63.9 \%$ を占めており, 特に医 師と検査技師の高龄化が顕著であった。（図 4A，B）。

輸血業務改善指導の経験については「ある」が 25 名 $(69.4 \%)$,「ない」が11名（30.6\%）であった（図 $4 \mathrm{C})$.

視察判定能力維持に必要と考える 5 年間の視察経験 数は 2 回が 12 名 $(33.3 \%)$ で最も多く, 3 回が 8 名 $(22.2 \%)$, 1 回が 7 名 (19.4\%), 5 回以上が 6 名 (16.7\%), 4 回が 3 名 (8.3\%) で, 2〜3 回で半数以上を占めた (図 4D).

3. 認定施設拡充に向けたシミュレーション

1）認定施設拡充について

認定施設拡充により地域差のない安全で適正な輸血 


\section{A 受審の提案者}

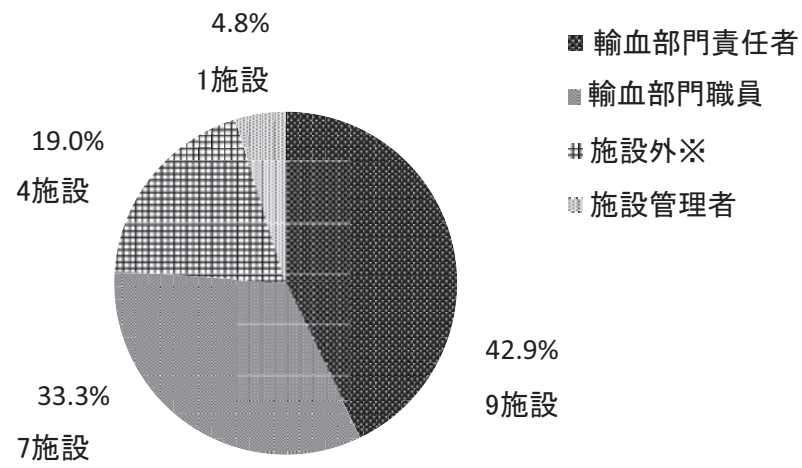

※施設外は、合同輸血療法委員会医師と 日本輸血·細胞治療学会医師

B 視察準備に苦慮した点
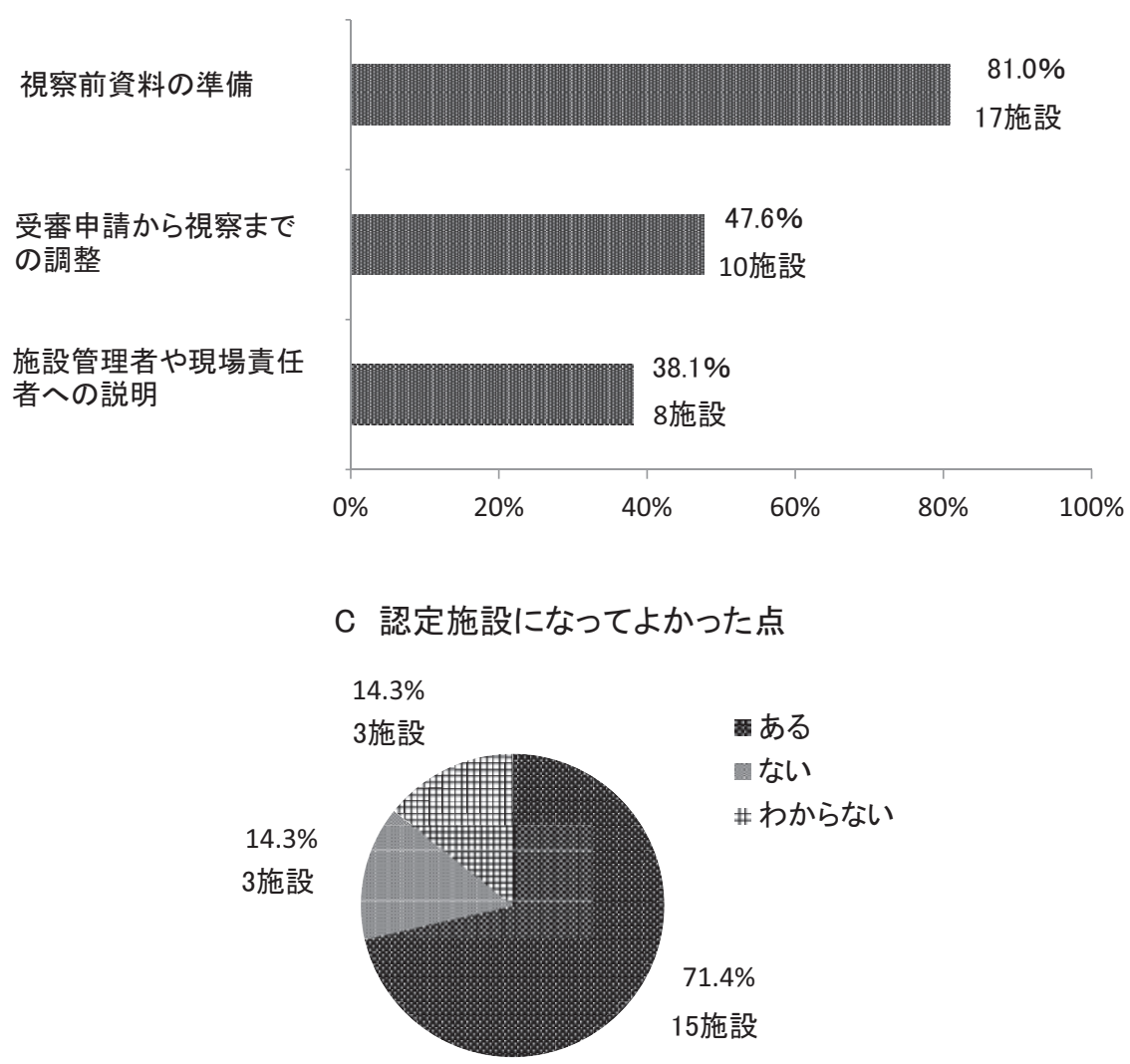

A : 受審の提案者

図 2 認定施設へのアンケート結果

輸血部門責任者 $42.9 \%$, 輸血部門職員 33.3\% で, 輸血部門関係者が全体の $76.2 \%$ を占めた。

$B ：$ 視察準備に苦虑した点

$\mathrm{C} ：$ 認定施設になってよかった点

認定施設になってよかった点がある具体例

・冷蔵庫などの購入のきっかけになった

・臨床認定看護師が 2 人でき, 看護部門の協力を得やすくなった

・県内のモデル病院としての波及効果が高い

・業務の標準化がはかれた

・冷蔵庫の温度管理がしっかりできるようになった

・病院機能評価では I\&A 認証施設でほぼパスできる

・スタッフの輸血に対する考え方に変化がみられる 


\section{A どのようになればI\&Aを受審するか}

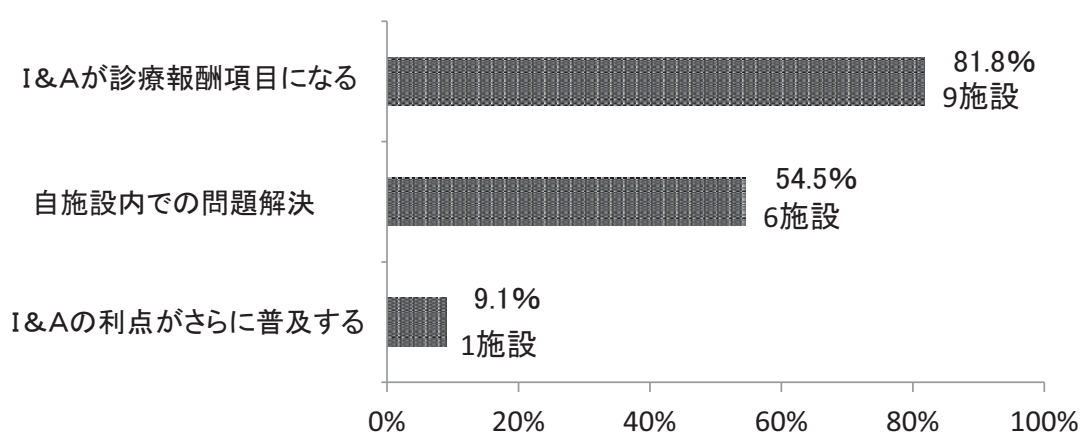

$B$ 受審を阻害する要因

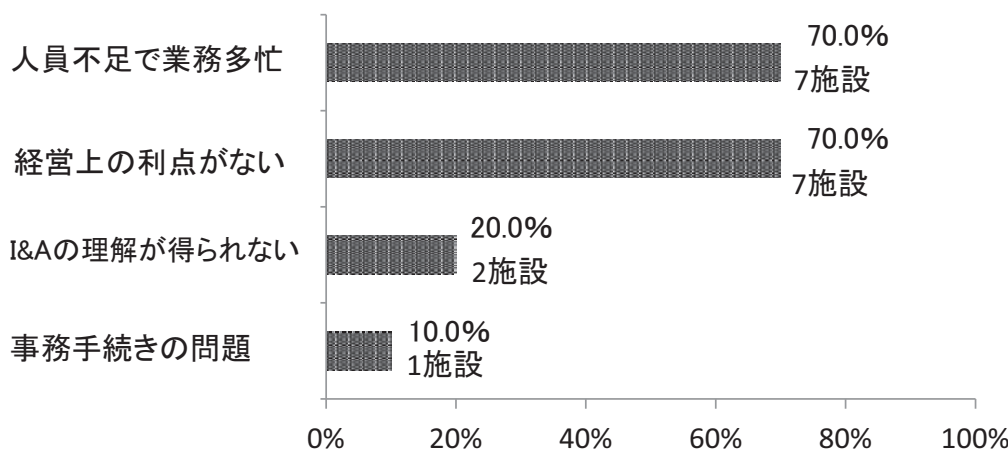

図 3 輸血管理料 I 取得の I\&A 未受審施設へのアンケート結果

A：どのようになればI\&A 受審するか

どのようになればI\&A を受審するかの環境面での問題では「I\&A が診療報酬項目に なる」が $81.8 \%$ で最多で, 次に「自施設内での問題解決」が $54.5 \%$ である.

B : 受審を阻害する要因

受審を阻害する自施設での問題点は, 「人員不足で業務多忙」と「経営上の利点がない」 が $70.0 \%$ で大勢を占める。

が普及することを目的にシミュレーションを行い， 5 年後に輸血管理料 I 取得施設の $80 \%$ が認定される数值 目標を設けた. 東海地区 4 県には輸血管理料 I 取得施設 が 75 施設あり (2017 年 11 月現在)，うち I\& A 認定施 設は 2018 年 4 月時点で 29 施設 (38.7\%) である。数值 目標の $80 \%$ である 60 施設に, 5 年後に達するためには, 今後毎年 6 施設以上の新規認定施設を増やすことが必 要となる。

2）確保すべき視察員数について

まず，数值目標の $80 \%$ である 60 施設の視察を 5 年 間で行うためには, 毎年 12 施設の視察を実施すること が必要であると推測した。

認定施設拡充のために必要な視察員数を「視察能力 維持に必要な視察経験数」から算出した。

視察能力維持に必要と考える 5 年間の視察経験数は, アンケート結果で $2 \sim 3$ 回が半数以上を占めている中,
5 回以上（16.7\%）も無視できない数值のため便宜上 3 回とした。

各年の視察合計回数を 12 回とすると, 視察員が 1 年間に 1 回視察した場合 12 名が必要である. 5 年間の 計 60 視察を 1 名の視察員が 3 回担当した場合には 20 名が必要となる。

医師, 検查技師, 看護師それぞれ 1 名ずつで視察チー ムを作った場合, 各職種ともこの 20 名が基準となる.

(1)医師における視察員の充足率予測

医師の視察員は 2018 年 3 月時点で 12 名在籍してい るが, 東海 4 県の輸血認定医が 70 名 ${ }^{3)}$ と限られており, 毎年最低限の 1 名を確保した場合でも 5 年後は 17 名 （充足率 85.0\%）であり充足は困難である（図 5A）.

(2)看護師に扔ける視察員の充足率予測

看護師の視察員は 2018 年 3 月時点で 17 名在籍して おり, 新たに毎年 3 名ずつ確保すれば 5 年後に 32 名 
A 視察員の年齢

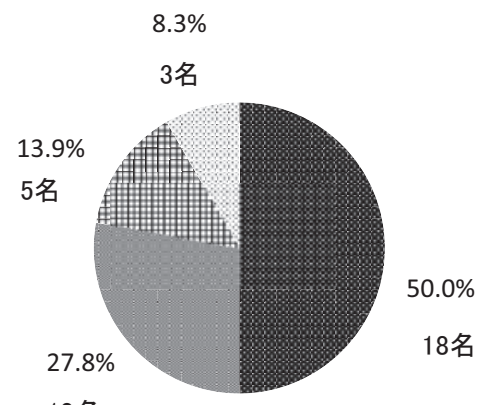

10名
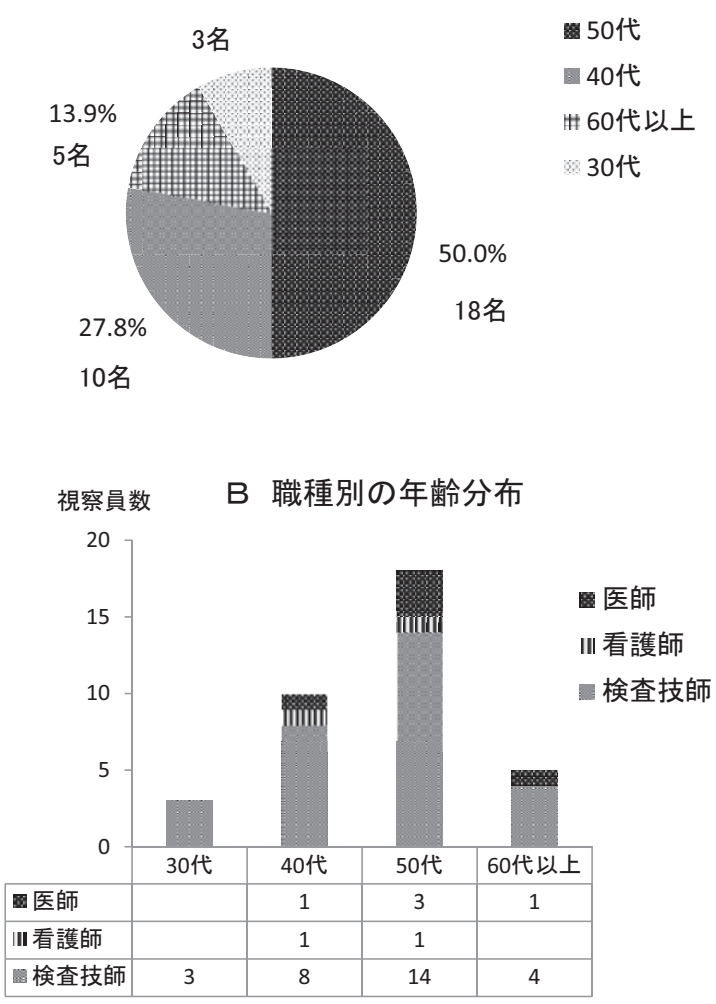

C 輸血業務改善指導の経験

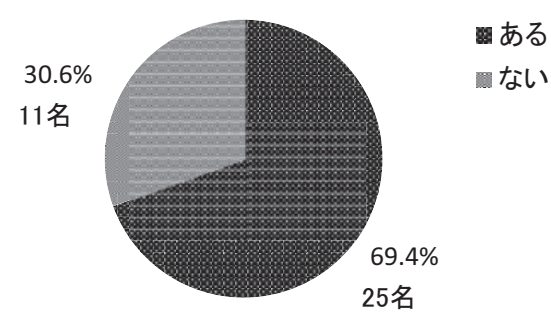

D 視察判定能力維持に必要と考える5年間の視察経験数

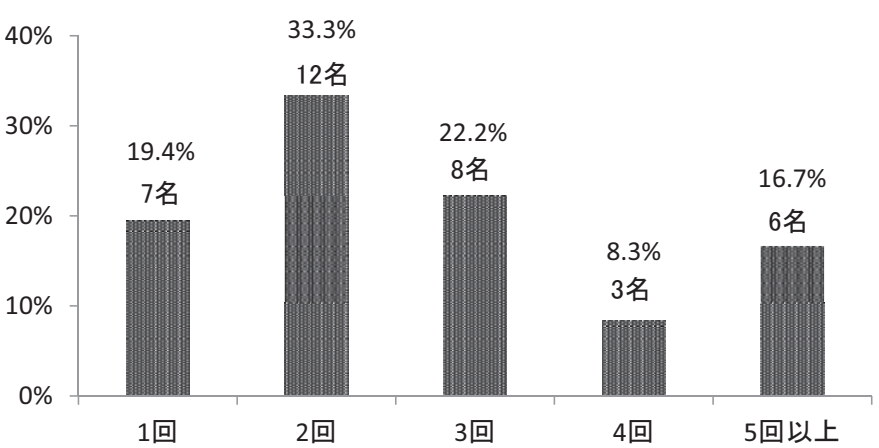

$\mathrm{A}:$ 視察員の年齢

図4 視察員へのアンケート結果

50 代 $50.0 \%, 60$ 代以上 $13.9 \%$ で, 50 歳以上の視察員が全体の $63.9 \%$ を占める.

$\mathrm{B}:$ 職種別の年齢分布

50 歳以上の視察員は, 医師 $80.0 \%$, 検査技師 $62.1 \%$ と高齢化が顕著である.

$\mathrm{C}$ : 輸血改善指導の経験

他施設への輸血業務改善指導の経験のある視察員は, その経験のない視察員の約 2.3 倍である.

$\mathrm{D}$ : 視察判定能力維持に必要と考える 5 年間の視察経験数

視察判定能力維持に必要と考える 5 年間の視察経験数は, 2 回 12 名（33.3\%）と 3 回 8 名（22.2\%）で，半数以上を占めている.

（充足率 160.0\%）となる. 東海 4 県の学会認定・臨床輸 血看護師が 132 名) と十分数在籍しているため養成は可 能であると思われる (図 5B).

(3)検查技師における視察員の充足

検査技師の視察員は 2018 年 3 月時点で 59 名在籍し ており充足している.

\section{考察}

支部全体として ver.5に移行後, 認定施設の増加が見 られている.これは, 学会関係者による I\&A 改革の取 り組み ${ }^{5}$ と共に本会議により各県間の情報と受審推進の 認識が共有され，支部全体の活動となったことも一因 と考えられる。

アンケート調査に打ける視察員からの回収率が $54.5 \%$ と不十分である理由は, 回収期間が 1 カ月と短く十分 に周知できなかったことに加え退職者への連絡が困難 であったことなどが影響したと考える.
認定施設拡充の課題については山内ら ${ }^{6}$ が I\&A の認 知度を高めることと視察員の養成について報告してい るが，今回の調查からは特に業務に携わる輸血部門関 係者に認定施設の利点を理解してもらい, 視察への不 安や疑問の解消, 視察前資料準備の負担を軽減させる 支援体制が必要と考えられ，併せて学会から厚労省へ の診療報酬上の働きかけが期待される.

また視察員においては特に医師と検查技師の高齢化 が目立ち, 退職などで活動を離れる視察員数を考慮す ると 5 年後の視察員確保は数值以上の困難が予測され るため, 若手のリクルート推進は急務で, それぞれへ の積極的なアプローチとともに検查技師においては視 察に参加することで得られる豊富な情報を地域に還元 しうる指導的立場として活躍できる点のアピールも有 効と考える.

今後, 認定施設を拡充させる上で視察側の負担を軽 減するために年次的に計画的な受審スケジュールをた 


\section{A 医師の視察員を毎年1名確保した場合の充足率予測}

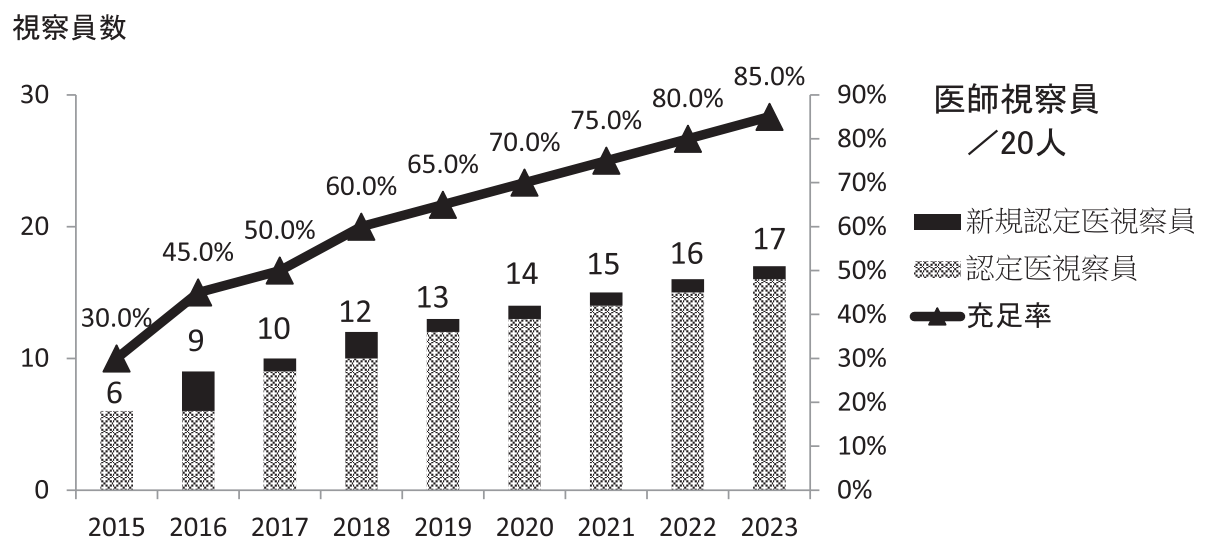

\section{B 看護師の視察員を毎年3名確保した場合の充足率予測}

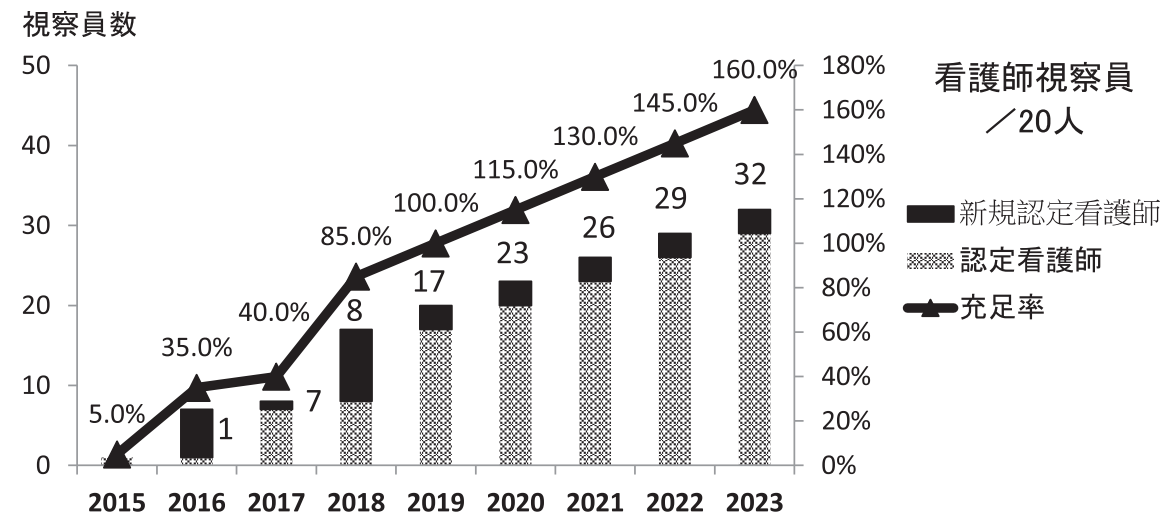

図 5 医師と看護師視察員の充足シミュレーション

A：医師視察員を毎年 1 名確保した場合の充足率予測

輸血認定医師数が限られており，毎年最低限の 1 名を確保した場合でも 5 年後の充足率は 85.0\%であり，充足が困難であることが予測される．

B : 看護師視察員を毎年 3 名確保した場合の充足率予測

学会認定・臨床輸血看護師が十分数在籍しているため, 毎年 3 名を確保すれば 5 年後に充足 率 $160.0 \%$ であり，養成が可能であることが予測される.

てる必要がある。また，視察員の確保はかねてからの 課題であるが7, 医師の不足は特に大きな課題であり今 後も医師の満足な充足が望めないことが予測されるた め, 医師の確保が困難な状況においては，経験豊富な 視察員が医師に代わって主任視察員を務めることも一 案と考える.

著者の COI 開示：本論文発表内容に関連して特に申告なし 本稿の要旨は第 66 回日本輸血・細胞治療学会総会で発表した. 謝辞：東海支部におけるI\&A の普及と推進には, 静岡市立清 水病院の長田広司先生のご尽力によるところが大きく,この場を 借りて深謝致します。

\section{文献}

1）田中朝志：学会からの㧍知らせ I\&Aの改革について. 日本輸血細胞治療学会誌, 61 : 巻末 $29,2015$.

2) 田中朝志 : 大改革 : 輸血機能評価制度 (I\&A)。週刊医 学のあゆみ, 258：1183-1188, 2016.

3）日本輸血・細胞治療学会ホームページ：認定医一覧. http://yuketsu.jstmct.or.jp/c_physician_list/（2018 年 4 月現在). 
4）日本輸血・細胞治療学会ホームページ：学会認定・臨床 輸血看護師一覧.

http://yuketsu.jstmct.or.jp/ct_nurse_list/（2018 年 4 月現在).

5）日本輸血・細胞治療学会ホームページ：輸血機能評価認 定制度（I\&A 制度）について。

http://yuketsu.jstmct.or.jp/authorization/about_i_a/ (2018 年 4 月現在)
6）山内史朗, 北澤淳一, 田中一人, 他：東北地区に抢ける I\&A（点検と認証）活動の取り組み一さらなるI\&A 活動の発展に向けて一. 日本輸血細胞治療学会誌, 59 : $819-825,2013$

7）星 順隆：I\&Aの目的と活用. 日本輸血細胞治療学会 誌, $57:$ 423—429, 2011.

\section{PRESENT STATUS AND PROSPECT OF INSPECTION AND ACCREDITATION PROGRAM (I\&A) IN TOKAI REGION}

Shoji Hashigaya ${ }^{1122}$, Tadasu Tobita ${ }^{2122}$, Hiroshi Kosugi ${ }^{3122}$, Shigehisa Tamaki ${ }^{4122}$, Takanobu Ando $^{5122}$, Katsutoshi Hasegawa ${ }^{612)}$, Mitsuko Maruyama ${ }^{7 / 12)}$, Tsuyoshi Morimoto ${ }^{8122}$, Yuko Ito ${ }^{9122}$, Chiyoshi Inoue ${ }^{1012)}$, Hitoshi Shindo ${ }^{1112)}$ and Hidefumi Kato ${ }^{5122}$

${ }^{1)}$ Division of Clinical Laboratory, Yaizu City Hospital

${ }^{2)}$ Chemotherapy Center, Iwata City Hospital

${ }^{3)}$ Department of Hematology, Ogaki Municipal Hospital

${ }^{4)}$ Department of Hematology, Division of Transfusion and Cell Therapy, Japanese Red Cross Ise Hospital

${ }^{5}$ Department of Transfusion Medicine, Aichi Medical University Hospital

${ }^{6}$ Department of Facilities, Fujita Health University

${ }^{7)}$ Department of Transfusion and Cell Therapy, Mie University Hospital

${ }^{8}$ Department of Transfusion Medicine, Matsunami General Hospital

${ }^{9}$ Center of Transfusion Medicine, Ogaki Municipal Hospital

${ }^{10)}$ Division of Clinical Laboratory, Okanami General Hospital

${ }^{111}$ Department of Nursing, Shizuoka City Shizuoka Hospital

${ }^{12)}$ Promotion Committee for I\&A of Tokai Region

\section{Keywords:}

I\&A, promotion committee for I\&A

(C)2019 The Japan Society of Transfusion Medicine and Cell Therapy Journal Web Site: http://yuketsu.jstmct.or.jp/ 